\title{
STATUS HUKUM ANAK LUAR KAWIN PASCA PUTUSAN MAHKAMAH KONSTITUSI NOMOR 46/PUU-VIII/2010
}

\author{
Ida Martinelli \\ Fakultas Keguruan dan Ilmu Pendidikan \\ Universitas Muhammadiyah Sumatera Utara \\ E-mail: idamartinelli1964@gmail.com
}

\begin{abstract}
Decision of Constitutional Court gives the child outside the civil status married to the biological father, the purpose of which provide legal protection to children outside of mating, so that the child's rights as a whole can be obtained. The legal relationship between the child outside of mating with her biological father must be proven with science and technology and/or other evidence according to the law have blood relations.
\end{abstract}

\section{Kata Kunci: Anak Luar Kawin, Mahkamah Konstitusi, Perlindungan Hukum}

\section{A. Latar Belakang}

Pergaulan hidup berumahtangga dibina dalam suasana damai, tenteram dan rasa kasih sayang antara suami isteri. Anak keturunan dari hasil perkawinan yang sah menghiasi kehidupan keluarga dan sekaligus merupakan kelangsungan hidup manusia secara bersih dan terhormat (Hamid Sarong 2005: 1-2). Anak merupakan amanah sekaligus karunia Allah SWT, bahkan anak dianggap sebagai harta kekayaan yang paling berharga dibandingkan harta kekayaan atau harta benda lainnya. Anak sebagai amanah Allah SWT harus senantiasa dijaga dan dilindungi, karena dalam diri anak melekat harkat, martabat, dan hak-hak sebagai manusia yang harus dijunjung tinggi (Andi Syamsu Alam dan Fauzan 2008: 1).

Anak (keturunan) sebagai sendi utama bagi pembentukan negara dan bangsa diperoleh melalui perkawinan, sehingga perkawinan sangat penting dalam pergaulan masyarakat bagi pembentukan masyarakat negara. Perkawinan adalah suatu perjanjian yang diadakan oleh dua orang (akad), dalam hal ini perjanjian antara seorang pria dengan seorang wanita dengan tujuan materil, yakni membentuk keluarga (rumah tangga) yang bahagia dan kekal, haruslah berdasarkan 
Ketuhanan Yang Maha Esa, sebagai asas utama dalam Pancasila (Soedharyo Soimin 2010: 6).

Ajaran agama Islam mensyari'atkan perkawinan (pernikahan) sebagai cara yang dipandang sah untuk menjaga dan memelihara kemurnian nasab. Islam memandang bahwa kemurnian nasab sangat penting, karena hukum Islam sangat terkait dengan struktur keluarga, baik hukum perkawinan, maupun kewarisan dengan berbagai derivasinya, yang meliputi hak perdata dalam hukum Islam, baik menyangkut hak nasab, hak perwalian, hak memperoleh nafkah dan hak mendapatkan warisan, bahkan konsep ke-mahram-an atau kemuhriman dalam Islam akibat hubungan persemendaan atau perkawinan. Bersamaan dengan perintah kawin (nikah), dalam hukum Islam juga diharamkan zina, karena zina menyebabkan tidak terpeliharanya nasab secara sah (Nurul Irfan 2013: 7).

Seorang anak dapat dikatakan sah memiliki hubungan nasab dengan ayahnya jika terlahir dari perkawinan yang sah. Sebaliknya anak yang lahir di luar perkawinan yang sah tidak dapat disebut anak yang sah, biasa disebut dengan anak zina atau anak di luar perkawinan yang sah (Amiur Nuruddin dan Azhari Akmal 2004: 276). Menurut Kitab Undang-undang Hukum Perdata (KUH Perdata), anak zina atau anak di luar perkawinan yang sah tidak mempunyai hubungan nasab dengan ayah biologisnya, kecuali setelah adanya pembuktian dan pengakuan dari ayahnya tersebut. Begitu juga dengan anak yang dilahirkan dari pernikahan siri, status anak yang dilahirkan dianggap sebagai anak tidak sah karena menurut hukum negara, pernikahan siri merupakan pernikahan yang tidak sah, konsekuensinya anak hanya mempunyai hubungan perdata dengan ibu dan keluarga ibunya, sebagaimana yang ditentukan dalam Pasal 42 dan Pasal 43 Undang-undang Nomor 1 Tahun 1974 tentang Perkawinan (UU No. 1 Tahun 1974), serta Pasal 100 Instruksi Presiden Nomor 1 Tahun 1991 tentang Kompilasi Hukum Islam (KHI).

Salah satu kasus ketidakjelasan nasab anak ini adalah kasus yang dialami oleh Aisyah Muchtar, karena pernikahan siri yang dilakukannya tanpa adanya pencatatan perkawinan. Pihaknya mengajukan permohonan kepada Mahkamah Konstitusi agar nasab anaknya dapat dinasabkan kepada Ayahnya. Setelah uji 
materil, maka Mahkamah Konstitusi mengabulkan permohonan yang telah diajukan dan menghadirkan keputusan baru yaitu dalam Putusan Mahkamah Konstitusi Nomor 46/PUU-VIII/2010 tentang Pengujian Pasal 43 ayat (1) UU No. 1 Tahun 1974, bahwa nasab anak luar nikah mengikuti nasab ayah biologisnya setelah dibuktikan dengan ilmu pengetahuan dan teknologi dan/atau alat lainnya menurut hukum mempunyai hubungan darah. Adanya Putusan Mahkamah Konstitusi ini menimbulkan kontroversi (perdebatan) dari para ahli hukum, sehingga hal ini menarik untuk diteliti lagi, yang tujuannya untuk menjawab persoalan yang terkait dengan status hukum anak luar kawin pasca Putusan Mahkamah Konstitusi tersebut.

\section{B. Metode Penelitian}

Penelitian yang terkait dengan status hukum anak luar kawin pasca Putusan Mahkamah Konstitusi Nomor 46/PUU-VIII/2010 merupakan penelitian yuridis normatif, dengan pendekatan perbandingan hukum. Sifat penelitiannya adalah deskriptif, maksudnya bahwa penelitian ini difokuskan untuk mendeskripsikan status hukum anak luar kawin. Sumber data penelitian yang diambil dalam penelitian ini adalah data sekunder, baik berupa bahan hukum primer, bahan hukum sekunder, maupun bahan hukum tersier, sedangkan metode pengumpulan data yang digunakan adalah metode studi dokumen. Data yang terkumpul dianalisis dengan menggunakan analisis kualitatif.

\section{Klasifikasi Anak dalam Perspektif Hukum Islam dan Peraturan Perundang-undangan di Indonesia}

Di Indonesia terdapat beberapa stelsel hukum yang mengatur kedudukan anak, yakni Hukum Perdata Barat (BW), Hukum Islam, Hukum Adat, dan Hukum Nasional produk Pemerintah Indonesia, yaitu berupa undang-undang, peraturan pemerintah, dan yurisprudensi Mahkamah Agung, termasuk Surat Edaran Mahkamah Agung Republik Indonesia. Ketentuan dalam hukum perkawinan yang diatur dalam KUH Perdata, sepanjang telah diatur dalam UU No. 1 Tahun 1974, maka dengan sendirinya tidak berlaku lagi. Hal ini didasarkan pada ketentuan 
Pasal 66 UU No. 1 Tahun 1974 dan berdasarkan asas lex posterior derogate lex priori (peraturan yang berlaku kemudian membatalkan peraturan terdahulu).

Dalam beberapa peraturan hukum yang berlaku di Indonesia tersebut dikenal beberapa macam istilah anak, yaitu: anak sah, anak luar kawin, anak zina, anak sumbang (incest), anak angkat, dan anak tiri. Dalam pranata hukum di Indonesia, istilah-istilah tersebut mempunyai konotasi yang berbeda, sehingga mempengaruhi pula terhadap kedudukan seorang anak dalam perspektif hukum (M. Anshary 2014: 1).

Konsep yuridis terhadap istilah anak, sebagaimana tersebut di atas, dapat dijelaskan sebagai berikut:

\section{Anak sah}

Seorang anak dapat dikatakan sah memiliki nasab dengan ayahnya jika terlahir dari perkawinan yang sah. Sebaliknya anak yang lahir di luar perkawinan yang sah, tidak dapat disebut dengan anak sah, biasanya disebut dengan anak zina atau anak luar perkawinan yang sah dan ia hanya memiliki hubungan nasab dengan ibunya. Menurut Pasal 42 UU No. 1 Tahun 1974, yang dikatakan anak sah adalah: "Anak yang dilahirkan dalam atau sebagai akibat perkawinan yang sah". Pada Pasal 99 KHI, disebutkan pula bahwa anak yang sah adalah: (a) anak yang dilahirkan dalam atau akibat perkawinan yang sah; dan (b) hasil pembuahan suami isteri yang sah di luar rahim dan dilahirkan oleh isteri tersebut.

Kedua ketentuan ini mempunyai rumusan yang sama tentang apa yang dikatakan anak sah, dan terkesan sangat umum, serta tidak memberikan batasan yang jelas dan tegas soal anak sah itu. Dari rumusan kedua pasal tersebut dapat ditarik garis hukum sebagai kriteria seorang anak itu dikatakan anak sah. Pertama, bahwa anak yang sah adalah anak yang dilahirkan dalam perkawinan yang sah; dan kedua, anak yang sah adalah anak yang dilahirkan sebagai akibat perkawinan yang sah (M. Anshary 2014: 2).

Memperhatikan ketentuan Pasal 42 UU No. 1 Tahun 1974, dapat dikatakan bahwa di dalamnya ada toleransi hukum kepada anak yang lahir dalam perkawinan yang sah, walaupun jarak antara pernikahan dan kelahiran anak kurang dari batas waktu minimal usia kandungan, sehingga selama bayi yang 
dikandung itu lahir pada saat ibunya dalam ikatan perkawinan yang sah, maka anak tersebut adalah anak sah. Undang-undang tidak mengatur batas minimal usia kandungan, baik dalam pasal-pasalnya maupun dalam penjelasannya (Ahmad Rofiq 2013: 178). Demikian pula Pasal 99 KHI, mengandung pembaruan hukum dalam mengantisipasi kemungkinan terjadinya bayi tabung, yaitu proses ovulasi yang direkayasa di luar rahim, melalui tabung yang disiapkan untuk itu, kemudian dimasukkan lagi ke dalam rahim isteri, dan dilahirkan juga oleh isteri tersebut, tetapi tetap dibatasi antara suami dan isteri yang terikat oleh perkawinan yang sah. (Ahmad Rofiq 2013: 179).

Kedua ketentuan (Pasal 42 UU No. 1 Tahun 1974 dan Pasal 99 KHI) tersebut mempunyai rumusan yang sama tentang apa yang dikatakan anak sah. Ketentuan yang terdapat dalam UU No. 1 Tahun 1974, maupun KHI tersebut terkesan sangat umum dan tidak memberikan batasan yang jelas dan tegas soal anak sah itu, begitupun dalam penjelasan pasal dinyatakan "cukup jelas", sehingga dari rumusan pasal tersebut dapat mengundang penafsiran yang berdisparitas, dan dari rumusan kedua pasal di atas, dapat ditarik garis hukum sebagai kriteria anak itu dapat dikatakan anak sah. Pertama, bahwa anak yang sah adalah anak yang dilahirkan dalam perkawinan yang sah; kedua, anak yang sah adalah anak yang dilahirkan sebagai akibat perkawinan yang sah (M. Anshary 2014: 2).

Pada Pasal 102 KHI tidak merinci batas minimal dan maksimal usia bayi dalam kandungan sebagai dasar suami untuk menyangkal sah tidaknya anak yang dilahirkan isterinya.

a. Suami yang akan mengingkari seorang anak yang lahir dari isterinya, mengajukan gugatan kepada Pengadilan Agama dalam jangka waktu 180 hari sesudah hari lahirnya atau 360 hari sesudah putusnya perkawinan atau setelah suami itu mengetahui bahwa isterinya melahirkan anak dan berada di tempat yang memungkinkan dia mengajukan perkaranya kepada Pengadilan Agama.

b. Pengingkaran yang diajukan sesudah lampau waktu tersebut tidak dapat diterima.

Pasal $102 \mathrm{KHI}$ itu juga tidak memberikan pernyataan yang jelas tentang batas minimal usia kandungan, karena ketetapan 360 hari tidak menunjukkan 
batas maksimal usia bayi dalam kandungan. Ketentuan 360 hari itu hanya menjelaskan batas waktu untuk mengajukan persoalannya ke Pengadilan Agama.

Alquran memberi petunjuk yang jelas tentang masalah batas usia minimal bayi dalam kandungan, yaitu 6 (enam) bulan dihitung dari saat akad nikah dilangsungkan. Ketentuan ini diambil dari firman Allah dalam surat al-Ahqaf ayat 15, sebagai berikut:

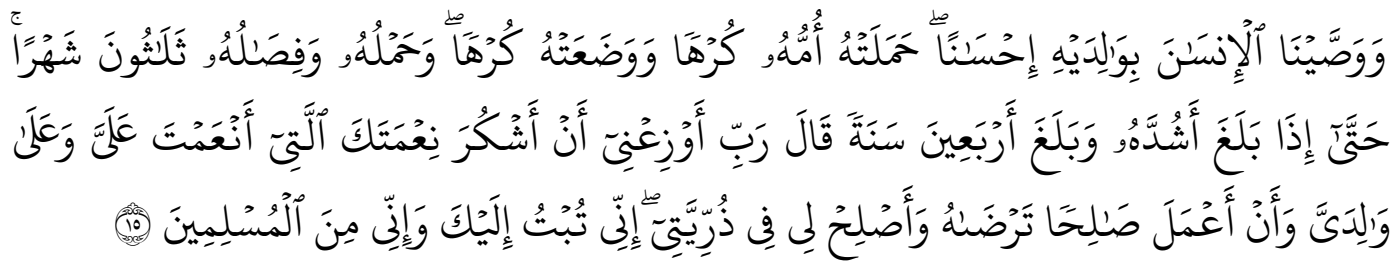

Artinya:

Kami perintahkan kepada manusia supaya berbuat baik kepada dua orang ibu bapaknya, ibunya mengandungnya dengan susah payah, dan melahirkannya dengan susah payah (pula). Mengandungnya sampai menyapihnya adalah tiga puluh bulan, sehingga apabila dia telah dewasa dan umurnya sampai empat puluh tahun ia berdoa: "Ya Tuhanku, tunjukilah aku untuk mensyukuri nikmat Engkau yang telah Engkau berikan kepadaku dan kepada ibu bapakku dan supaya aku dapat berbuat amal yang saleh yang Engkau ridhai; berilah kebaikan kepadaku dengan (memberi kebaikan) kepada anak cucuku. Sesungguhnya aku bertaubat kepada Engkau dan sesungguhnya aku termasuk orang-orang yang berserah diri”.

Kalimat "mengandungnya sampai menyapihnya dari penyusuannya adalah tiga puluh bulan", berarti bahwa dalam masa 6 (enam) bulan sebagai batas yang paling minimal dalam mengandung, sedangkan sisanya, yaitu masa 24 (dua puluh empat) bulan, adalah batas waktu maksimal penyusuan anak.

Selain itu, melalui firman Allah SWR dalam surat Luqman ayat 14, dijelaskan pula bahwa:

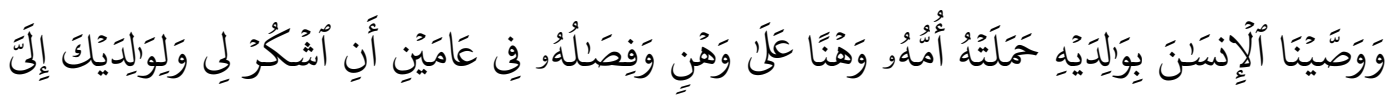
(ألَمَصِيرُ

Artinya: Dan Kami perintahkan kepada manusia (berbuat baik) kepada dua orang ibu bapaknya; ibunya telah mengandungnya dalam keadaan lemah yang bertambah-tambah, dan menyapihnya dalam dua tahun. Bersyukurlah kepada-Ku dan kepada dua orang ibu bapakmu, hanya kepada $\mathrm{Ku}$ lah kembalimu 
Berdasarkan kedua ayat tersebut di atas, dapat dimaklumi bahwa jika bayi lahir kurang dari enam bulan, tidak dapat dihubungkan kekerabatannya kepada bapaknya kendati pun dalam ikatan perkawinan yang sah. Ia hanya memiliki hubungan nasab kepada ibu dan keluarga ibunya saja. Pendapat semacam ini menjadi terasa kaku, sedangkan pada sisi lain, jika semua pihak konsisten dengan gagasan Alquran yang menekankan pembinaan moral, tentu akan dapat menyadari dan memakluminya. (Ahmad Rofiq 2013: 180).

Melalui analisis pandangan fikih berkenaan dengan anak sah ini, dapat dipahami bahwa anak sah dimulai sejak terjadinya konsepsi atau pembuahan sel telur (ovum) oleh sperma yang terjadi pada rahim wanita calon ibu dan konsepsi ini haruslah terjadi di dalam di dalam rahim perkawinan yang sah, dan dari sinilah penetapan anak sah tersebut dilakukan (Amiur Nuruddin dan Azhari Akmal Tarigan 2004: 278).

Hukum Islam menegaskan bahwa seorang anak agar dapat dianggap sebagai anak yang sah dari suami ibunya, maka anak itu harus lahir sekurangkurangnya enam bukan sesudah pernikahan atau di dalam tenggang 'iddah selama empat bulan sepuluh hari sesudah perkawinan terputus (Amiur Nuruddin dan Azhari Akmal Tarigan 2004: 280). Mengenai tenggang waktu ini ada aliran di antara ahli fikih yang berpendapat bahwa seorang anak yang lahir setelah melampaui tenggang 'iddah sesudah perkawinan terputus, adalah anak sah dari bekas suaminya asal dapat dianggap bahwa kelahirannya disebabkan oleh perbuatan bersetubuh antara bekas suami isteri itu (Amiur Nuruddin dan Azhari Akmal Tarigan 2004: 280).

Berdasarkan pendapat di atas, maka anak yang lahir kurang dari enam bulan sejak masa perkawinan, maka anak tersebut tidak dapat dihubungkan kekerabatannya dengan bapaknya, walaupun lahir dalam perkawinan yang sah. Si bayi hanya memiliki hubungan nasab dengan ibunya saja, dan dalam pandangan hukum Islam, dan menurut Abdul Manan (2006: 79) ada empat syarat agar nasab anak itu dianggap sah, yaitu:

a. Kehamilan bagi seorang isteri bukan hal yang mustahil, artinya normal dan wajar untuk hamil; 
b. Tenggang waktu kelahiran dengan pelaksanaan perkawinan minimal enam bulan sejak perkawinan dilaksanakan, dan ini merupakan ijma' (kesepakatan ulama) sebagai masa terpendek dari suatu kehamilan;

c. Anak yang lahir itu terjadi dalam waktu kurang dari masa sepanjang kehamilan; tentang hal ini masih terjadi perselisihan oleh pakar hukum Islam;

d. Suami tidak mengingkari anak tersebut melalui lembaga li'an, dan jika seorang laki-laki ragu tentang batas minimal tidak terpenuhi dalam masa kehamilan atau batas maksimal kehamilan terlampaui, maka ada alasan bagi suami untuk mengingkari anak yang dikandung oleh isterinya dengan cara li'an.

\section{Anak luar kawin}

Pengertian anak luar kawin (natuurlijk kind) dalam persepsi Hukum Islam dan KUHPerdata adalah berbeda. Hukum Islam memandang bahwa setiap hubungan seksual di luar perkawinan, apakah menyebabkan kehamilan atau tidak, adalah perzinaan, dan perbuatan zina merupakan dosa besar. Anak di luar kawin adalah anak yang dilahirkan oleh seorang perempuan, sedangkan perempuan itu tidak berada dalam ikatan perkawinan yang sah dengan pria yang menyetubuhinya (Abdul Manan 2006: 80).

Menurut Abdul Manan (2006: 81), dalam praktik hukum perdata pengertian anak luar kawin ada dua macam, yaitu:

a. Apabila orang tua salah satu atau keduanya masih terikat dengan perkawinan lain, kemudian mereka melakukan hubungan seksual dengan wanita atau pria lain yang mengakibatkan hamil dan melahirkan anak, maka anak tersebut dinamakan anak zina, bukan anak luar kawin;

b. Apabila orang tua anak di luar kawin itu masih sama-sama bujang, mereka mengadakan hubungan seksual dan hamil serta melahirkan anak, maka anak itu disebut anak luar nikah. Beda keduanya adalah anak zina dapat diakui oleh orang tua biologisnya, sedangkan anak di luar kawin dapat diakui oleh orang tua biologisnya apabila mereka menikah, dalam akta perkawinan dapat dicantumkan pengakuan (erkennen) di pinggir akta perkawinannya. 
Suatu perkawinan dikatakan sah menurut perspektif Hukum Islam apabila telah memenuhi rukun-rukun nikah, yakni wali nikah, dua orang saksi nikah, dan ijab qabul (akad). Hubungan biologis yang halal, dan anak yang dilahirkan sebagai akibat dari perkawinan semacam ini secara syar' $i$ dan yuridis dinyatakan sebagai anak yang sah. Hubungan biologis yang dilakukan tanpa melalui akad nikah, maka disebut dengan zina. Anak yang lahir dari akibat hubungan biologis tersebut disebut dengan anak zina atau anak luar kawin, meskipun anak tersebut dilahirkan dalam perkawinan yang sah karena wanita yang melahirkan anak tersebut dengan laki-laki yang menghamilinya (bapak biologis) kemudian melangsungkan perkawinan yang sah. Dalam pandangan hukum Islam, antara anak luar nikah dan anak zina ada dalam istilah dan makna yang sama.

Anak luar kawin adalah anak yang dilahirkan oleh seorang ibu, tetapi ia tidak dibenihkan oleh seorang laki-laki yang terikat hubungan perkawinan sah dengan wanita lain, dan tidak pula termasuk kategori anak sumbang atau anak zina. Intinya, anak luar kawin adalah anak yang lahir dari hubungan seksual seorang laki-laki dan perempuan yang keduanya masih berstatus lajang, dan dilakukan dengan cara suka sama suka, dan telah berusia 15 (lima belas) tahun atau lebih. Anak yang dilahirkan di luar nikah (anak luar kawin) dalam BW (Burgerlijk Wetboek) dinamakan natuurlijke kind (M. Anshary 2014:59).

Pasal 43 ayat (1) UU No. 1 Tahun 1974, menentukan bahwa anak yang dilahirkan di luar perkawinan hanya mempunyai hubungan perdata dengan ibunya dan keluarga ibunya. Berdasarkan ketentuan ini, dapat diketahui bahwa anak luar kawin adalah anak yang dilahirkan di luar perkawinan dan hanya memiliki hubungan keperdataan dengan ibunya saja. Artinya adalah anak yang dibenihkan dan dilahirkan di luar perkawinan yang sah, disebut anak luar nikah dan hanya mempunyai hubungan keperdataan dengan ibu yang melahirkannya dan keluarga ibunya saja, sedangkan anak yang dibenihkan di luar perkawinan, tetapi kemudian dilahirkan dalam perkawinan yang sah, maka menurut ketentuan Pasal 42 UU No. 1 Tahun 1974, maka anak tersebut dipandang sebagai anak yang sah.

Ada satu hal kontroversi jika melihat status anak tidak sah atau anak luar kawin yang kemudian "dilegitimasi" oleh undang-undang. Kontroversialnya 
adalah ada diktum dalam UU No. 1 Tahun 1974, yang menyebutkan bahwa anak sah adalah anak yang lahir "dalam perkawinan yang sah", jelas sekali pengertian ini tidak menghiraukan terjadinya konsepsi si anak di dalam rahim (Amiur Nuruddin dan Azhari Akmal Tarigan 2004: 287). Ironisnya kawin hamil justru dijustifikasi oleh KHI seperti yang terdapat di dalam Pasal 53 yang menyatakan bahwa:

Ayat (1): seorang wanita hamil di luar nikah, dapat dikawinkan dengan pria yang menghamilinya.

Ayat (2): perkawinan dengan wanita hamil yang dimaksud pada ayat (1), dapat dilangsungkan tanpa menunggu lebih dahulu kelahiran anaknya.

Ayat (3): dengan dilangsungkannya perkawinan saat wanita hamil, tidak diperlukan perkawinan ulang setelah anak yang dikandung lahir.

\section{Akibat Hukum Putusan Mahkamah Konstitusi Nomor 46/PUU-VIII/2010 terhadap Status Hukum Anak Luar Kawin}

Diskriminasi serta ketidakadilan perilaku dan sikap lahiriah kepada anak, sering terjadi di masyarakat, yang pengaruhnya tentu tidak baik bagi pembentukan karakter anak, bahkan untuk masa depan anak. Diskriminasi tersebut dapat terjadi dimana saja dan oleh siapa saja, termasuk di lingkungan keluarga.

Diskriminasi terhadap anak dalam lingkungan keluarga, misalnya ketika kedua orang tua tidak menjaga keadilan dalam perilaku dan sikap lahiriahnya di antara anak-anak, maka yang seharusnya kehidupan di lingkungan keluarga berjalan harmonis, justru sebaliknya akan menimbul percekcokan pada sesama anggota keluarga, karena akibat diskriminasi ini sendiri akan mempengaruhi seluruh anggota keluarga, padahal berdasarkan Pasal 28B ayat (2) UUD 1945, ditentukan bahwa setiap anak berhak atas kelangsungan hidup, tumbuh, dan berkembang, serta berhak atas perlindungan dari kekerasan dan diskriminasi. Ironisnya, pemerintah dan berbagai elemen masyarakat lainnya selalu menghimbau agar jangan ada diskriminasi terhadap anak, tetapi jika diperhatikan peraturan perundang-undangan yang berlaku (seperti UU No. 1 Tahun 1974), justru diskriminasi ini sendiri masih dilegalisasi. 
Khusus terkait dengan UU No. 1 Tahun 1974, masih ada ketentuan yang bersifat diskriminatif, hal ini berkenaan dengan kedudukan anak dalam keluarga, bahwa berdasarkan Pasal 42 dan 43 UU No. 1 Tahun 1974 anak yang sah adalah anak yang dilahirkan dalam perkawinan yang sah, dan anak yang dilahirkan dari perkawinan yang tidak sah hanya mempunyai hubungan hukum dengan ibunya dan keluarga ibunya. Ketentuan ini jika ditinjau dari kepentingan anak, akan memberatkan bagi ibunya dan juga terhadap diri anak itu sendiri, sebab pengertian perkawinan yang sah dalam konteks ini, yang apabila dihubungkan dengan Pasal 2 ayat (1) UU No. 1 Tahun 1974, maka anak yang lahir dari perkawinan tidak tercatat dianggap sebagai anak tidak sah, dengan kata lain tidak mempunyai hubungan perdata dengan ayah biologisnya.

Adanya diskriminasi terhadap anak akibat ketentuan tersebut di atas, telah menimbulkan ketidakpastian hukum terhadap hak waris anak dari ayah biologisnya, sehingga pada tahun 2010 telah diajukan permohonan kepada Mahkamah Konstitusi (uji materil) terhadap Pasal 43 ayat (1) UU No. 1 Tahun 1974. Pihak yang terkait dalam uji materil Pasal 43 ayat (1) UU No. 1 Tahun 1974 kepada Mahkamah Konstitusi ini yaitu, pihak Pemohon adalah Machicha Mochtar seorang mantan isteri siri (almarhum) Moerdiono yang telah memiliki seorang anak bernama M. Iqbal Ramadhan, tetapi anak tersebut tidak mendapat pengakuan secara hukum negara sebagai anak ayah kandungnya, karena pernikahannya tidak dicatat di lembaga pernikahan resmi di Indonesia, yaitu Kantor Urusan Agama (KUA) dengan alasan bahwa pada saat ibunya menikah dengan (almarhum) Moerdiono, beliau masih terikat perkawinan dengan isteri yang lain, sehingga tidak dapat dicatat. Akibat lebih lanjut bahwa M. Iqbal Ramadhan kehilangan hak mewaris dari (almarhum) Moerdiono.

Awalnya nikah siri ditujukan atau dimaknakan terhadap perkawinan yang tidak memenuhi rukun dan syarat perkawinan sebagaimana yang dikemukakan oleh Umar bin Khattab ketika beliau mendapat pengaduan perkara tentang perkawinan yang hanya disaksikan oleh seorang saksi laki-laki dan seorang saksi perempuan. Saat ini, pengertian nikah siri diperluas, yaitu termasuk perkawinan yang memenuhi rukun dan syarat perkawinan tetapi belum/tidak dicatatkan di 
Kantor Urusan Agama Kecamatan bagi orang yang beragama Islam (Abdi Koro 2012: 345).

Sejumlah alasan yang diajukan oleh pihak Pemohon dalam permohonan uji materil UU No. 1 Tahun 1974 dikemukakan bahwa Pemohon merupakan pihak yang secara langsung mengalami dan merasakan hak konstitusionalnya dirugikan dengan diundangkannya UU No. 1 Tahun 1974, terutama berkaitan dengan Pasal 2 ayat (2) dan Pasal 43 ayat (1). Pasal ini justru menimbulkan ketidakpastian hukum yang mengakibatkan kerugian bagi Pemohon berkaitan dengan status perkawinan dan status hukum anaknya yang dihasilkan dari hasil perkawinan. Alasan berikutnya bahwa hak konstitusional Pemohon yang telah dilanggar dan merugikan tersebut adalah hak sebagaimana dijamin dalam Pasal 28B ayat (1) dan Pasal 28B ayat (2) UUD 1945. Pasal-pasal pokok dalam UUD 1945 yang terkait hak asasi manusia itu merupakan alasan kuat bahwa pihak Pemohon dan anaknya memiliki hak konstitusional untuk mendapatkan pengesahan atas pernikahan dan status hukum anaknya, sedangkan hak konstitusional yang dimiliki oleh Pemohon telah dicederai oleh norma hukum dalam UU No. 1 Tahun 1974. Norma hukum ini jelas tidak adil dan merugikan karena perkawinan Pemohon adalah sah dan sesuai dengan rukun nikah dalam Islam. Merujuk ke norma konstitusional yang termaktub dalam Pasal 28B ayat (1) UUD 1945 maka perkawinan Pemohon yang dilangsungkan sesuai dengan rukun nikah adalah sah, tetapi terhalang oleh Pasal 2 ayat 2 UU Perkawinan.

Berdasarkan rumusan Pasal 2 ayat (2) UU No. 1 Tahun 1974, dapat diketahui bahwa norma hukum yang mengharuskan sebuah perkawinan dicatat menurut peraturan perundang-undangan yang berlaku telah mengakibatkan perkawinan yang sah dan sesuai dengan rukun nikah agama Islam (norma agama) menjadi tidak sah menurut norma hukum. Kemudian secara otomatis hal ini berdampak kepada status anak yang dilahirkan Pemohon ikut tidak menjadi sah menurut norma hukum dalam UU No. 1 Tahun 1974, sehingga jelas telah terjadi pelanggaran oleh norma hukum dalam UU No. 1 Tahun 1974 terhadap perkawinan Pemohon (norma agama). Hal senada juga disampaikan oleh Van Kan yang menyatakan bahwa "Kalau pelaksanaan norma-norma hukum tersebut tidak 
mungkin dilakukan maka tata hukum akan memaksakan hal lain, yang sedapat mungkin mendekati apa yang dituju norma-norma hukum yang bersangkutan atau menghapus akibat-akibat dari pelanggaran norma-norma hukum itu" (Nurul Irfan 2013: 136).

Pihak Pemohon berusaha keras untuk mengajukan uji materil ke Mahkamah Konstitusi dengan mengemukakan bahwa konsekuensi dari ketentuan Pasal 28B ayat (1) dan ayat (2) serta Pasal 28D ayat (1) UUD 1945 tersebut adalah setiap orang memiliki kedudukan dan hak yang sama termasuk haknya untuk mendapatkan pengesahan atas pernikahan dan status hukum anaknya. Norma konstitusi yang timbul dari Pasal 28B ayat (1) dan ayat (2) serta Pasal 28D ayat (1) adalah adanya persamaan dan kesetaraan di hadapan hukum.

Diskriminasi dalam penerapan norma hukum tidak ada terhadap setiap orang disebabkan cara pernikahan yang ditempuhnya berbeda dan anak yang dilahirkan dari pernikahan tersebut adalah sah di hadapan hukum, serta tidak diperlakukan berbeda, tetapi dalam praktiknya justru norma agama telah diabaikan oleh kepentingan pemaksa, yaitu norma hukum perkawinan Pemohon yang sudah sah berdasarkan rukun nikah dan norma agama Islam, menurut norma hukum menjadi tidak sah karena tidak tercatat menurut Pasal 2 ayat (2) UU No. 1 Tahun 1974 (Nurul Irfan 2013: 136-137).

Fungsi dan kedudukan pencatatan perkawinan, menurut Bagir Manan, adalah untuk menjamin ketertiban hukum yang berfungsi sebagai instrumen kepastian hukum, kemudahan hukum, selain sebagai salah satu alat bukti perkawinan, dan jika terjadi pasangan yang telah melakukan perkawinan yang sah menurut agama, karena itu telah sah pula menurut Pasal 2 ayat (1) UU No. 1 Tahun 1974, tetapi belum dicatat, maka cukup dilakukan pencatatan (Neng Djubaidah 2012: 159). Alasan lebih lanjut yang diajukan oleh pihak Pemohon, pemberlakuan norma hukum ini berdampak terhadap status hukum anak yang dilahirkan dari perkawinan Pemohon menjadi anak di luar nikah berdasarkan ketentuan norma hukum dalam Pasal 43 ayat (1) UU No. 1 Tahun 1974. Di sisi lain, perlakuan diskriminatif ini sudah tentu menimbulkan permasalahan karena status seorang anak di muka hukum menjadi tidak jelas dan sah. Padahal, dalam 
UUD 1945 dinyatakan anak terlantar saja, yang orang tuanya tidak jelas, dipelihara oleh negara.

Kenyataannya hal yang berbeda diperlakukan terhadap anak Pemohon yang dihasilkan dari perkawinan yang sah, sesuai dengan rukun nikah dan norma agama justru dianggap tidak sah oleh UU No. 1 Tahun 1974. Konstitusi Republik Indonesia tidak menghendaki sesuatu yang sudah sesuai dengan norma agama justru dianggap melanggar hukum berdasarkan norma hukum. Argumentasi kuat oleh pihak Pemohon bahwa Pemohon memiliki hubungan sebab-akibat antara kerugian konstitusional dengan berlakunya UU No. 1 Tahun 1974, khususnya Pasal 2 ayat (2) dan Pasal 43 ayat (1), yaitu yang berkaitan dengan pencatatn perkawinan dan hubungan hukum anak yang dilahirkan dari perkawinan yang tidak dicatatkan.

Pelanggaran atas hak konstitusional Pemohon sebagai warga negara Republik Indonesia telah terjadi, karena Pasal 2 ayat (2) dan Pasal 43 ayat (1) UU No. 1 Tahun 1974 tersebut bertentangan dengan Pasal 28B ayat (1) dan ayat (2) serta Pasal 28D ayat (1) UUD 1945. Hal ini mengakibatkan pernikahan Pemohon yang telah dilakukan secara sah dan sesuai dengan agama yang dianut Pemohon, yaitu agama Islam, tidak mendapatkan kepastian hukum pula.

UUD 1945 jelas-jelas menjamin dan melindungi hak-hak anak, tetapi kenyataannya sejak lahirnya anak Pemohon telah mendapat perlakuan diskriminatif, yaitu dengan dihilangkannya asal-usul dari anak Pemohon dengan hanya mencantumkan nama Pemohon dalam akta kelahirannya dan negara telah menghilangkan hak anak untuk kelangsungan hidup, tumbuh, dan berkembang karena dengan hanya mempunyai hubungan keperdataan dengan ibunya menyebabkan suami dari Pemohon tidak mempunyai kewajiban hukum untuk memelihara, mengasuh, dan membiayai anak Pemohon.

Tidak ada seorang anak pun yang dilahirkan di muka bumi ini dapat dipersalahkan dan diperlakukan diskriminatif, karena cara pernikahan yang ditempuh kedua orang tuanya berbeda, tetapi sah menurut ketentuan norma agama. Anak tersebut adalah anak yang sah secara hukum dan wajib diperlakukan sama di hadapan hukum. Kenyataannya maksud dan tujuan diundangkannya UU 
No. 1 Tahun 1974 berkaitan pencatatan perkawinan dan anak yang lahir dari sebuah perkawinan yang tidak dicatatkan, dianggap sebagai anak di luar perkawinan sehingga hanya mempunyai hubungan perdata dengan ibunya (Nurul Irfan 2013: 138).

Lebih lanjut pihak Pemohon berusaha mengemukakan berbagai alasan yuridis bahwa norma konstitusi yang termaktub dalam UUD 1945 salah satunya mengandung tujuan hukum. Tujuan hukum dapat ditinjau dari teori etis (etische theorie) yang menyatakan hukum hanya semata-mata bertujuan mewujudkan keadilan. Kelemahannya adalah peraturan tidak mungkin dibuat untuk mengatur setiap orang dan setiap kasus, tetapi dibuat untuk umum, yang sifatnya abstrak dan hipotesis. Kelemahan lainnya adalah hukum tidak selalu mewujudkan keadilan. Menurut teori utilitis (utilities theorie), hukum bertujuan mewujudkan semata-mata apa yang berfaedah saja. Hukum bertujuan menjamin adanya kebahagiaan sebanyak-banyaknya pada orang sebanyak-banyaknya. Kelemahannya adalah hanya memperhatikan hal-hal umum, dan terlalu individualistis, sehingga tidak memberikan kepuasan bagi perasaan hukum.

Teori selanjutnya adalah campuran dari kedua teori tersebut yang dikemukakan oleh para sarjana ini. Bellefroid menyatakan bahwa isi hukum harus ditentukan menurut dua asas, yaitu keadilan dan faedah. Utrecht menyatakan hukum bertugas menjamin adanya kepastian hukum (rechtszekerheid) dalam pergaulan manusia. Dalam tugas itu tersimpul dua tugas lain, yaitu harus menjamin keadilan serta hukum tetap berguna. Dalam kedua tugas tersebut tersimpul pula tugas ketiga yaitu hukum bertugas polisionil (politionele taak van het recht). Hukum menjaga agar dalam masyarakat tidak terjadi main hakim sendiri (eigenrichting). Wirjono Prodjodikoro berpendapat tujuan hukum adalah mengadakan keselamatan bahagia dan tertib dalam masyarakat.

Majelis Hakim Mahkamah Konstitusi berpendapat bahwa pokok permohonan para Pemohon, adalah pengujian konstitusionalitas Pasal 2 ayat (2) UU No. 1 Tahun 1974 yang menyatakan, "tiap-tiap perkawinan dicatat menurut peraturan perundang-undangan yang berlaku", dan Pasal 43 ayat (1) UU No. 1 Tahun 1974 yang menyatakan, "anak yang dilahirkan di luar perkawinan hanya 
mempunyai hubungan perdata dengan ibunya dan keluarga ibunya", khususnya mengenai hak untuk mendapatkan status hukum anak. Selanjutnya menimbang bahwa pokok permasalahan hukum mengenai pencatatan perkawinan menurut peraturan perundang-undangan adalah mengenai makna hukum (legal meaning) pencatatan perkawinan.

Mahkamah Konstitusi juga berpendapat bahwa pencatatan perkawinan bukanlah merupakan faktor yang menentukan sahnya perkawinan, dan pencatatan merupakan kewajiban administratif yang diwajibkan berdasarkan peraturan perundang-undangan. Adapun faktor yang menentukan sahnya perkawinan adalah syarat-syarat yang ditentukan oleh agama dari masing-masing pasangan calon mempelai. Diwajibkannya pencatatan perkawinan oleh negara melalui peraturan perundang-undangan merupakan kewajiban administratif.

Makna pentingnya kewajiban administratif berupa pencatatan perkawinan tersebut, menurut Mahkamah Konstitusi, dapat dilihat dari dua perspektif. Pertama, dari perspektif negara, pencatatan dimaksud diwajibkan dalam rangka fungsi negara memberikan jaminan perlindungan, pemajuan, penegakan, dan pemenuhan hak asasi manusia yang bersangkutan yang merupakan tanggung jawab negara dan harus dilakukan sesuai dengan prinsip negara hukum yang demokratis yang diatur serta dituangkan dalam peraturan perundang-undangan. Kedua, pencatatan secara administratif yang dilakukan oleh negara dimaksudkan agar perkawinan, di kemudian hari dapat dibuktikan dengan bukti yang sempurna dengan suatu akta otentik, sehingga perlindungan dan pelayanan oleh negara terkait dengan hak-hak yang timbul dari suatu perkawinan yang bersangkutan dapat terselenggara secara efektif dan efisien (Nurul Irfan 2013: 144-145).

Secara alamiah, tidaklah mungkin seorang perempuan hamil tanpa terjadinya pertemuan antara ovum dan spermatozoa, baik melalui hubungan seksual (coitus), maupun melalui cara lain berdasarkan perkembangan teknologi yang menyebabkan terjadinya pembuahan. Tidak tepat dan tidak adil manakala hukum menetapkan bahwa anak yang lahir dari suatu kehamilan karena hubungan seksual di luar perkawinan hanya memiliki hubungan dengan perempuan tersebut sebagai ibunya. Adalah tidak tepat dan tidak adil pula jika hukum membebaskan 
laki-laki yang melakukan hubungan seksual yang menyebabkan terjadinya kehamilan dan kelahiran anak tersebut dari tanggung jawabnya sebagai seorang bapak dan bersamaan dengan itu hukum meniadakan hak-hak anak terhadap lelaki tersebut sebagai bapaknya. Lebih-lebih manakala berdasarkan perkembangan teknologi yang ada memungkinkan dapat dibuktikan bahwa seorang anak itu merupakan anak dari laki-laki tertentu.

Mahkamah Konstitusi menimbang bahwa berdasarkan uraian tersebut di atas maka Pasal 43 ayat (1) UU No. 1 Tahun 1974 yang menyatakan, “anak yang dilahirkan di luar perkawinan hanya mempunyai hubungan perdata dengan ibunya dan keluarga ibunya" harus dibaca "anak yang dilahirkan di luar perkawinan mempunyai hubungan perdata dengan ibunya dan keluarga ibunya serta dengan laki-laki sebagai ayahnya yang dapat dibuktikan berdasarkan ilmu pengetahuan (antara lain keterangan ahli) dan teknologi (Tes DNA) dan/atau alat bukti lain (saksi, fakta, berkas perkara pengadilan, fatwa MUI) menurut hukum mempunyai hubungan darah, termasuk hubungan perdata dengan keluarga ayahnya".

Selanjutnya Mahkamah Konstitusi menimbang bahwa, berdasarkan seluruh pertimbangan di atas, maka dalil para Pemohon sepanjang menyangkut Pasal 2 ayat (2) UU No. 1 Tahun 1974 tidak beralasan menurut hukum. Adapun Pasal 43 ayat (1) UU No. 1 Tahun 1974 yang menyatakan, "anak yang dilahirkan di luar perkawinan hanya mempunyai hubungan perdata dengan ibunya dan keluarga ibunya" adalah bertentangan dengan UUD 1945 secara bersyarat (conditionally unconstitutional), yaitu inkonstitutional sepanjang ayat tersebut dimaknai menghilangkan hubungan perdata dengan laki-laki yang dapat dibuktikan berdasarkan ilmu pengetahuan dan teknologi dan/atau alat bukti lain menurut hukum mempunyai hubungan darah sebagai ayahnya.

Sehubungan dengan uraian di atas, dapat dikatakan bahwa pencatatan perkawinan tidak merupakan syarat sah suatu perkawinan, karena syarat sah perkawinan adalah sesuai syarat atau ketentuan yang terdapat dalam ajaran (kaedah) agama, tetapi pencatatan perkawinan mutlak harus dilaksanakan demi melindungi hak-hak para pihak dalam satu keluarga, yang terdiri dari suami, isteri dan anak/anak-anak yang dilahirkan dari perkawinan itu. Melalui pencatatan 
perkawinan yang diikuti dengan terbitnya Buku Nikah, akan dapat membuktikan bahwa seseorang memang benar sedang terikat dalam satu ikatan perkawinan, sehingga para pihak dapat menuntut hak-haknya dan dituntut untuk memenuhi kewajibannya yang tertuang dalam UU No. 1 Tahun 1974. Dengan demikian, pencatatan perkawinan dilakukan bukan bertujuan untuk membuktikan sahnya perkawinan dalam pengertian sah menurut agama, tetapi semata-mata hanya sebagai pengakuan (legalisasi) dari negara bahwa para pihak dalam perkawinan memang benar terikat dalam suatu ikatan perkawinan, dengan kata lain untuk membuktikan identitas diri seseorang bahwa dirinya adalah benar suami atau isteri dari seseorang, serta untuk membuktikan status seorang anak sebagai anak dari pasangan suami isteri.

Hal ini sesuai dengan pertimbangan Mahkamah Konstitusi yang menyebutkan bahwa faktor yang menentukan sahnya perkawinan adalah syaratsyarat yang ditentukan oleh agama dari masing-masing pasangan calon mempelai. Diwajibkannya pencatatan perkawinan oleh negara melalui peraturan perundangundangan merupakan kewajiban administratif. Makna pentingnya kewajiban administratif berupa pencatatan perkawinan tersebut, menurut Mahkamah, dapat dilihat dari dua perspektif, yaitu:

a. dari perspektif negara, pencatatan dimaksud diwajibkan dalam rangka fungsi negara memberikan jaminan perlindungan, pemajuan, penegakan, dan pemenuhan hak asasi manusia yang bersangkutan yang merupakan tanggung jawab negara dan harus dilakukan sesuai dengan prinsip negara hukum yang demokratis yang diatur serta dituangkan dalam peraturan perundang-undangan vide Pasal 28I ayat (4) dan ayat (5) UUD 1945. Sekiranya pencatatan dimaksud dianggap sebagai pembatasan, pencatatan demikian menurut Mahkamah tidak bertentangan dengan ketentuan konstitusional karena pembatasan ditetapkan dengan undang-undang dan dilakukan dengan maksud semata-mata untuk menjamin pengakuan serta penghormatan atas hak dan kebebasan orang lain, dan untuk memenuhi tuntutan yang adil sesuai dengan pertimbangan moral, nilai-nilai agama, keamanan, dan ketertiban umum dalam suatu masyarakat demokratis vide Pasal 28J ayat (2) UUD 1945. 
b. pencatatan secara administratif yang dilakukan oleh negara dimaksudkan agar perkawinan, sebagai perbuatan hukum penting dalam kehidupan yang dilakukan oleh yang bersangkutan, yang berimplikasi terjadinya akibat hukum yang sangat luas, di kemudian hari dapat dibuktikan dengan bukti yang sempurna dengan suatu akta otentik, sehingga perlindungan dan pelayanan oleh negara terkait dengan hak-hak yang timbul dari suatu perkawinan yang bersangkutan dapat terselenggara secara efektif dan efisien. Artinya, dengan dimilikinya bukti otentik perkawinan, hak-hak yang timbul sebagai akibat perkawinan dapat terlindungi dan terlayani dengan baik, karena tidak diperlukan proses pembuktian yang memakan waktu, uang, tenaga, dan pikiran yang lebih banyak, seperti pembuktian mengenai asal-usul anak dalam Pasal 55 UU No. 1 Tahun 1974 yang mengatur bahwa bila asal-usul anak tidak dapat dibuktikan dengan akta otentik maka mengenai hal itu akan ditetapkan dengan putusan pengadilan yang berwenang. Pembuktian yang demikian pasti tidak lebih efektif dan efisien bila dibandingkan dengan adanya akta otentik sebagai buktinya.

\section{E. Simpulan dan Saran}

\section{Simpulan}

Kesimpulan dari Putusan Mahkamah Konstitusi mengenai status hukum anak luar kawin yaitu bahwa anak yang dilahirkan di luar perkawinan tidak hanya mempunyai hubungan perdata dengan ibunya dan keluarga ibunya saja tetapi juga mempunyai hubungan perdata dengan laki-laki sebagai ayahnya dan keluarga ayahnya setelah dapat dibuktikan dengan ilmu pengetahuan dan teknologi dan/atau alat bukti lainnya menurut hukum mempunyai hubungan darah.

\section{Saran}

Sehubungan Pasal 43 ayat (1) UU No. 1 Tahun 1974 telah dinyatakan oleh Mahkamah Konstitusi adalah bertentangan dengan UUD 1945, yaitu Pasal 28B ayat (1) dan ayat (2) serta Pasal 28D ayat (1) UUD 1945, maka terhadap anak yang lahir dari perkawinan siri (perkawinan tidak tercatat), harus dianggap sebagai anak sah. 


\section{DAFTAR PUSTAKA}

\section{Buku:}

Abdi Koro. 2012. Perlindungan Anak di Bawah Umur. Bandung: P.T Alumni.

Abdul Manan. 2006. Aneka Masalah Hukum Perdata Islam di Indonesia. Jakarta: Kencana Prenada Media Group.

Ahmad Rofiq. 2013. Hukum Perdata Islam di Indonesia. Jakarta: PT RajaGrafindo Persada. Edisi Revisi.

Amiur Nuruddin dan Azhari Akmal. 2004. Hukum Perdata Islam di Indonesia. Jakarta: Prenadia Media.

Andi Syamsu Alam dan Fauzan. 2008. Hukum Pengangkatan Anak Perspektif Islam. Jakarta: Pena Media.

Anshary, M. 2014. Kedudukan Anak dalam Perspektif Hukum Islam dan Hukum Nasional. Bandung: CV. Mandar Maju.

Hamid Sarong. 2005. Hukum Perkawinan Islam di Indonesia. Banda Aceh: Yayasan PeNa.

Neng Djubaidah. 2012. Pencatatan Perkawinan dan Perkawinan Tidak Dicatat. Jakarta: Sinar Grafika.

Nurul Irfan. 2013. Nasab dan Status Anak dalam Hukum Islam. Jakarta: Amzah.

Soedharyo Soimin. 2010. Hukum Orang dan Keluarga. Jakarta: Sinar Grafika.

\section{Peraturan Perundang-undangan:}

Republik Indonesia, Undang-Undang Dasar Negara Tahun 1945.

Republik Indonesia, Undang-undang Nomor 1 Tahun 1974 tentang Perkawinan.

Republik Indonesia, Instruksi Presiden Nomor 1 Tahun 1991 tentang Kompilasi Hukum Islam.

Republik Indonesia, Putusan Mahkamah Konstitusi Nomor 46/PUU-VII/2010. 


\section{BIODATA PENULIS}

$\begin{array}{ll}\text { Nama } & : \text { Ida Martinelli } \\ \text { Pekerjaan } & : \text { Fakultas Keguruan dan Ilmu Pendidikan Universitas } \\ & \text { Muhammadiyah Sumatera Utara } \\ \text { Jabatan } & : \text { Lektor Kepala } \\ \text { Nomor HP } & : \text { 085277368705 } \\ \text { E-mail } & : \text { idamartinelli1964@gmail.com } \\ \text { Alamat Kantor } & : \text { Jl. Kapten Muchtar Basri No. 3, Medan }\end{array}$

